\title{
Ssiendo
}

DOI 10.2478/afepuc-2020-0013

(C) Acta Facultatis Educationis Physicae Universitatis Comenianae 2020, 60(2): 158-169

\section{PLYOMETRIC EXERCISES IMPROVES MUSCULAR POWER AND DIGITAL ACHIEVEMENT IN HIGH JUMP AMONG STUDENTS}

\author{
Benzidane Houcine, Mokrani Djamel, Attalah Ahmed \\ Laboratory of Programs Optimization in APS, Institute of Physical Education and Sports, \\ Universityof Mostaganem, Algeria
}

\begin{abstract}
Summary: The research aim was to identify the effect of using some plyometric exercises to improve muscular power (vertical jump) and digital achievement in high jump activity among third year's students. The researchers used an experimental method in conformity with research nature between pre-tests and post-tests for the sample research. The sample was formed by students belonging to the physical education and sports institute, University of Mostaganem (Algeria) of the academic year 2018/2019. 40 students were chosen and divided into two groups (experimental 21 students, control 19 students). The vertical jump test of stability and digital achievement test were used. After the treatment of the results by statistical means and through these results, it has been reached several conclusions from them. Plyometric exercises are important to develop vertical jump and digital achievement level in high jump [discussion significant difference $(\mathrm{p} \leq 0.05)]$ among students, and the best improvement of the experimental group based on plyometric exercises is marked comparing to the control group.
\end{abstract}

Keywords: plyometric exercises, muscular power, vertical jump, digital achievement, high jump

\section{Introduction}

Athletics games are considered among events that attracted attention in the area of research thing which led to the improvement in various training methods. As consequence there were improvements concerning records in run, jump and throwing competitions at different international levels. This kind of games depends on muscle strength at jump and throws competitions. The muscle strength is an important element to achieve any sort of physical performance. Its contribution varies according to the kind of performance and 
contributes to the appreciation of other physical elements as speed, endurance and agility. For that, it has occupied part in sport training programs and it's considered as an important determinant in achieving sport superiority at most of athletics games events.

A review of the published literature produces a common definition of plyometric exercise. (Fatouros et al. 2000), (Moore et al. 2005) report plyometric exercises as those that are characterized by a rapid deceleration of the body followed almost immediately by a rapid acceleration of the body in the opposite direction. It is this eccentric/concentric contraction pattern which is reported to evoke the elastic properties of the muscle fibers and connective tissue in a way that allows the muscle to store more elastic energy during the deceleration phase and release it during the acceleration period. Zabchi et al. (2016), Benzidane et al. (2015), Mokrani et al.(2015), Bensikaddour et al.(2015), Hamdi (2011) mentioned that plyometric training and plyometric exercises contribute in improving the achievement especially in activities that use explosive muscles contractions.

Bal et al. (2011) says that the concept of plyometric training program is divided into three ranks based on the volume and intensity. The plyometric exercise program has low, middle, and high, the low plyometric exercise prepares muscles and basic skills, namely power, strength, muscle endurance, and balance to turn into better and more complex skills, the middle plyometric exercise aims to give stimulus in order to improve fitness' components (Bal et al. 2011). And the high plyometric exercise aims to shape specific skills based on the particular sport. This plyometric training program is a conditioning method intensely. It is better for young silat fighters to start the training with low intensity then improve it later (Alptekin \& Mavis 2013).

The research problem due to researchers field follow-upin the area of teaching students in athletics specialty at physical education and sports institutes, It's, also, noticed students weak performance in the jump as well as slower speed concerning the approximate sprint add to bad standing which require a height speed and strong fast while approaching. This is what students do suffer from in the high jump. This what let us to notice the reasons of digital achievement weakness in high jump due to the lack of using training methods without looking for means and methods which may fulfill sport superiority. For that, researchers suggested to know the effect of using some plyometric exercises on legs strength to realize the digital achievement in the high jump effectiveness among third year's students of sports and physical education, university of Mostaganem, Algeria.

\section{Objective:}


- Using plyometric exercises to develop muscular power (vertical jump) among students (third year) sports and physical education,

- Using plyometric exercises to develop the performance in the high jump of students (third year) during sports and physical education,

- To identify the differences between pre and post-tests for members of the research group.

\section{Methods}

Research Methodology: Researchers used experimental method reliving to the nature and the problematic of the research.

Research Society and Sample: Search community were selected from third-year LMD students physical education and sports, Institute of physical education and sports of Mostaganem (Algeria), 40 students ranging in age between 20 to 22 years of the academic year 2018/2019, 40 students were chosen from males and were divided into two groups as follows: Group one is the experimental group (21 students), and the second group is the control group (19 students). Knowing that (Table 1), all of them belong to the same level and the same specialization (athletics).

Table 1

Sample Specifications

\begin{tabular}{|l|c|c|c|c|}
\hline \multirow{2}{*}{ Variables } & $\begin{array}{c}\text { Experimental } \\
\text { group }\end{array}$ & Control group & \multirow{2}{*}{ T } & $\begin{array}{c}\text { Difference } \\
\text { significances }\end{array}$ \\
\cline { 2 - 3 } & Mean \pm SD & Mean $\pm S D$ & & \\
\hline Age (years) & $21.82 \pm 4.16$ & $21.12 \pm 4.28$ & 0.52 & \multirow{2}{*}{ No Significant } \\
\hline height $[\mathrm{m}]$ & $1.72 \pm 0.35$ & $1.73 \pm 0.48$ & 0.07 & \\
\hline Weight $[\mathrm{kg}]$ & $69.29 \pm 5.10$ & $68.50 \pm 5.63$ & 0.46 & \\
\hline BMI $\left[\mathrm{kg} / \mathrm{m}^{2}\right]$ & $23.48 \pm 3.87$ & $22.83 \pm 3.90$ & 0.52 \\
\hline Vertical jump $[\mathrm{cm}]$ & $39.33 \pm 5.07$ & $37.73 \pm 5.34$ & 0.96 & \\
\hline Achievement $[\mathrm{m}]$ & $1.59 \pm 0.22$ & $1.55 \pm 0.38$ & 0.25 & \\
\hline
\end{tabular}

T Tabular $=1.69$

\section{Test 1: vertical jump to the top from stability "Sargent"}

The purpose of the test: Measuring muscle power of the legs.

Tools: Chalk, measuring tape, wall.

Performance specifications: The student stands next to the wall and extends his arms to the top in order to determine the brand with chalk. Then he moves arms, bends forward and down, bends his knees and then jump towards the top to determine the second mark. 
Recording: The distance is measured between the two brands in centimeters (Fig. 1).

\section{Test 2: High Jump Test}

The aim of the test: measurement of distance achievement for high jump Tools used: measurement band of distances, high jump track.

Performance description: each athlete was selected after controlling the approximate distance to the standing board. Three (03) attempts were given to every athlete recording the highest achievement. The distance was measured to the last trace left by the athlete (Fig. 2).
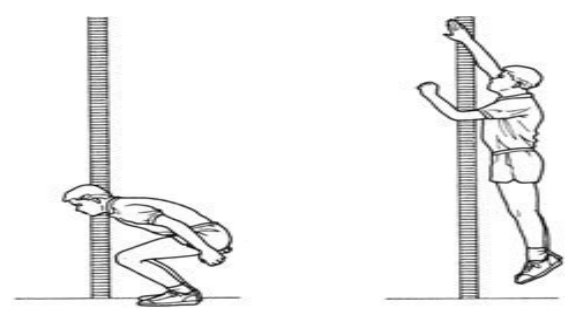

Figure 1

The vertical jump test

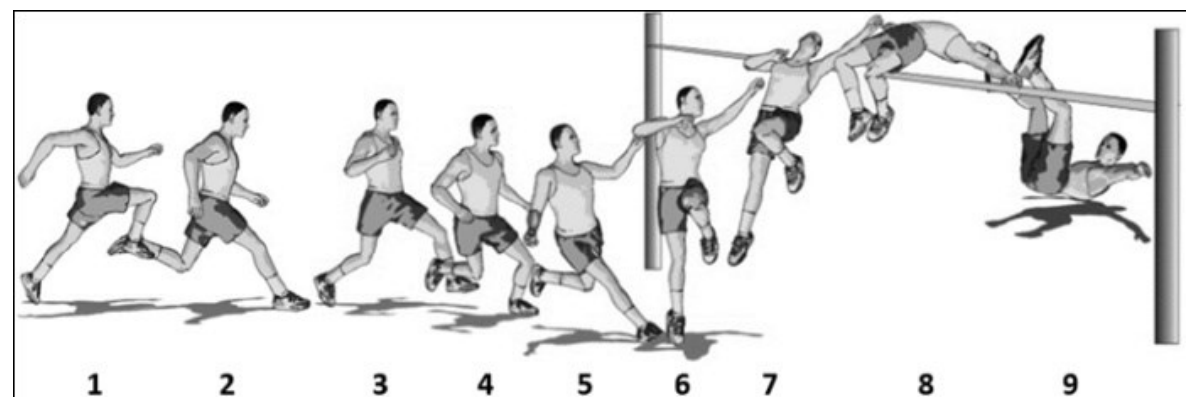

Figure 2

The high jump test

\section{The Main Experience}

Training sessions for research sample were held in the morning of each Monday and Wednesday. Set of plyometric exercises were prepared aiming to develop legs muscular strength for third year students of physical education and sports by using the necessary tools and means, was practiced 2 days per week for 6 weeks. Each session had its own procedural aim beginning from Feb. 04 ${ }^{\text {th }}, 2019$ to Mar. 13 ${ }^{\text {th }}, 2019$.

\section{Data Analysis}

The results are presented as the mean \pm standard deviation (SD). The mean and standard deviation were calculated with the measured results, paired T-test was applied for mean 
difference test between groups. Statistical significant level was set at $\alpha=0.05$.

Table 2

The content of the program (plyometric exercises)

\begin{tabular}{|c|c|c|c|}
\hline Weeks & Week 1 & Week 2 & Week 3 \\
\hline Exercises & $\begin{array}{l}\text { - Double leg jump forward } \\
(2 \times 10) \\
\text { - Double leg jump backward } \\
(2 \times 10) \\
\text { - Pogo jump }(2 \times 10) \\
\text { - Double leg hop }(2 \times 10) \\
\text { - Power skipping }(2 \times 10)\end{array}$ & $\begin{array}{l}\text { - Double leg jump forward } \\
(3 \times 8) \\
\text { - Pogo jump }(3 \times 8) \\
\text { - Zig Zag Double leg hops } \\
\text { (3x8) } \\
\text { - Double leg target jump }(3 \times 8) \\
\text { - Mini squat jump }(3 \times 8)\end{array}$ & $\begin{array}{l}\text { - Jump \& turn } 90^{\circ}(4 \times 8) \\
\text { - Knee tuck jump }(3 \times 8) \\
\text { - Single leg jump forward } \\
(3 \times 8) \\
\text { - Alternating Leg Hops }(3 \times 8) \\
\text { - lateral box push-offs }(3 \times 8)\end{array}$ \\
\hline Intensity & $70-80 \%$ & $70-80 \%$ & $80-90 \%$ \\
\hline $\begin{array}{l}\text { Rest between } \\
\text { exercises }\end{array}$ & $15-25 \mathrm{~s}$ & $15-25 \mathrm{~s}$ & $30-40 s$ \\
\hline $\begin{array}{c}\text { Rest between } \\
\text { sets }\end{array}$ & $1-2 m$ & $1-2 m$ & $2-3 m$ \\
\hline Weeks & Week 4 & Week 5 & Week 6 \\
\hline Exercises & $\begin{array}{l}\text { - Single leg jump forward } \\
(3 \times 8) \\
\text { - Knee tuck jump }(3 \times 8) \\
\text { - Alternating Leg Hops }(3 \times 8) \\
\text { - lateral box push-offs }(4 \times 8) \\
\text { - ball or bench taps }(3 \times 8) \\
\text { - Power skipping }(4 \times 8) \\
\end{array}$ & $\begin{array}{l}\text { - Incremental vertical jump } \\
(3 \times 6) \\
\text { - Single leg vertical jump (3x6) } \\
\text { - Squat jump }(3 \times 6) \\
\text { - Scissor Jumps }(3 \times 6) \\
\text { - Pogo jump }(3 \times 6) \\
\text { - Power skipping }(3 \times 6)\end{array}$ & $\begin{array}{l}\text {-Single leg vertical jump (3x6) } \\
\text { - Pogo jump }(3 \times 6) \\
\text { - Drop depth jump }\left(6^{*} 3\right) \\
\text { - Jump \& turn } 180^{\circ}(3 \times 6) \\
\text { - double leg drop jump over a } \\
\text { hurdle }(3 \times 6) \\
\text { - Power skipping }(3 \times 6) \\
\end{array}$ \\
\hline Intensity & $80-90 \%$ & $90-100 \%$ & $90-100 \%$ \\
\hline $\begin{array}{l}\text { Rest between } \\
\text { exercises }\end{array}$ & $30-40 \mathrm{~s}$ & $60 \mathrm{~s}$ & $60 \mathrm{~s}$ \\
\hline $\begin{array}{l}\text { Rest between } \\
\text { sets }\end{array}$ & $2-3 m$ & $3-4 m$ & $3-4 m$ \\
\hline
\end{tabular}

\section{Results}

Viewing, analyzing the vertical jump test

Table 3

Comparisons between the pre-test and post-test results in the vertical jump

\begin{tabular}{|c|c|c|c|c|c|c|}
\hline $\begin{array}{c}\text { Statistical means } \\
\text { Research Sample }\end{array}$ & N & Pre-test & Post test & $\begin{array}{c}\text { T } \\
\text { Calculated }\end{array}$ & $\begin{array}{c}\text { T } \\
\text { Tabulated }\end{array}$ & $\begin{array}{c}\text { Difference } \\
\text { significances }\end{array}$ \\
\hline Control group & 19 & $37.33 \pm 5.34$ & $42.19 \pm 5.11$ & $2.51^{*}$ & 1.73 & Significant \\
\hline $\begin{array}{c}\text { Experimental } \\
\text { group }\end{array}$ & 21 & $39.33 \pm 5.07$ & $47.84 \pm 4.61$ & $3.43^{*}$ & 1.72 & Significant \\
\hline
\end{tabular}

The results of table 3, after using the significance differences test, shows that the calculated $\mathrm{T}$ value for the control group amounted to 2.51 which is superior than tabulated Testimated to 1.73 at the degree of freedom 18 and the level of significance 0.05 which means the existence of statistical significance. Concerning the experimental group the calculated $\mathrm{T}$ 
value amounted to 3.43 which are superior than the value of tabulated T estimated to 1.72 at the degree of freedom 20 and significant level 0.05 that means the existence of statistical significance which means the existence of significant difference between averages in favor of the post-test.

\section{Viewing, analyzing the high jumptest}

\section{Table 4}

Comparisons between the pre-test and post-test results of Achievement in high jump

\begin{tabular}{|c|c|c|c|c|c|c|}
\hline $\begin{array}{c}\text { Statistical means } \\
\text { Research Sample }\end{array}$ & $\mathbf{N}$ & Pre-test & Post-test & $\begin{array}{c}\text { T } \\
\text { Calculated }\end{array}$ & $\begin{array}{c}\text { T } \\
\text { Tabulated }\end{array}$ & $\begin{array}{c}\text { Difference } \\
\text { significances }\end{array}$ \\
\cline { 3 - 7 } & Mean \pm SD & Mean \pm SD & & 1.73 & No Significant \\
\hline Control group & 19 & $1.55 \pm 0.38$ & $1.62 \pm 0.20$ & 1.68 & 1.72 & Significant \\
\hline Experimental group & 21 & $1.59 \pm 0.22$ & $1.76 \pm 0.17$ & $3.72^{*}$ & \multicolumn{1}{|l}{} \\
\hline
\end{tabular}

Through the statistical results mentioned in table 4, after using the measurement of statistical significance $\mathrm{T}$ student, we notice that the calculated T value for the control group amounted to 1.68 which is smaller than the tabulated T value estimated to 1.73 at the degree of freedom 18 and significant level 0.05 which means the existence of statistical significance. As for the experimental group the value of calculated T amounted to 3.72 which superior than tabulated $\mathrm{T}$ amounted to 1.72 at the degree of freedom 20 and significant level 0.05 that means the existence of statistical significance which means also the existence of significant difference between the pre and post calculated average in favor of the post-test.

\section{Comparison of post-test results of research samples}

Table 5

Comparisons between experimental and control groups in Post-test ( $\left.{ }^{*} p \leq 0.05\right)$

\begin{tabular}{|c|c|c|c|c|c|}
\hline Statistical means & $\begin{array}{c}\text { Control } \\
\text { group }\end{array}$ & $\begin{array}{c}\text { Experimental } \\
\text { group }\end{array}$ & $\begin{array}{c}\text { T } \\
\text { Calculated }\end{array}$ & $\begin{array}{c}\text { T } \\
\text { Tabulated }\end{array}$ & $\begin{array}{c}\text { Difference } \\
\text { significances }\end{array}$ \\
\cline { 2 - 3 } & Mean $\pm \mathrm{SD}$ & Mean $\pm \mathrm{SD}$ & & \\
\hline Vertical jump $(\mathrm{cm})$ & $42.19 \pm 5.11$ & $47.84 \pm 4.61$ & $3.28^{*}$ & \multirow{2}{*}{2.04} & Significant \\
\hline Achievement $(\mathrm{m})$ & $1.62 \pm 0.20$ & $1.76 \pm 0.17$ & $2.33^{*}$ & Significant \\
\hline
\end{tabular}

We do notice through Table 5, that the calculated $\mathrm{T}$ value amounted between 2.33 as smallest value and 3.28 as biggest value which is bigger than tabulated T estimated to 2.04 at the degree of freedom 38 and significant level 0.05 which confirms the presence of significant 
differences between these averages that means the differences have statistical significance.

\section{Discussion}

Through the Table 3, we notice improvement the vertical jump for the experimental group in comparison with the control group. This due to the use of plyometric exercises aiming at a rate of twice a week with specific intensities (70\% to $100 \%)$, and includes a set of exercises such as (Double leg jump, Pogo jump, Power skipping, Zig-Zag Double leg hops, Squat jump...) to improve and develop legs power by activating voluntary muscles in work. This method leads to produce and output strength maximum to fulfill the bestresult, because leg strength is the primary source of power in many sports. According to Gambetta (2007) the legs can be seen as a functional unit of a closed kinetic chain without which an athlete cannot have speed, strength, power or suppleness to perform (Gambetta 2007). And plyometric training is an excellent method of developing body power and it is proved a very effective method for improving explosive strength. It offers rich variation of exercise and load structure any activity that activates that stretch reflex mechanism is Plyometric exercise (Henson 1994).

Also, the control group made some progress in the vertical jump test as a result of applying a group of jump exercises and during the practical lesson, which formed a kind of competition among students to achieve better results. Where she came in favor of the experimental group.

Where it leads to the development of muscular power and then leads to the production of high ability and fast dynamic performance. The use of plyometric exercises to develop legs muscles explosive power emphasizes to increase the push in advance due to the speed of the working muscles extension resulting from training and adapted to reduce the default time while executing the push in front of which increase the jump distance. Many studies (Holcomb et al.1996; Stojanović \& Kostić 2002; Makaruk et al.2010; Kotzamanidis 2006; Ramirez-Campillo et al. 2014a; Sozbir 2016; Thakur et al 2016) mentioned that the use of training with plyometric exercises contribute to the improvement the explosive power for low parties after applying the jump test. The results agreed with the results obtained which confirm the effectiveness of the plyometric training method use to improve low parties (legs) explosive strength.

The results of Table 4 show also that the experimental group members had achieved the best results in post-test compared with control group members. This confirms the improvement of both experimental group levels due to proposed exercises included for the 
experimental sample in order to develop the digital achievement in high jump. The series of the performed plyometric exercises ranged in a set of different plyometric leaps confirmed their effective impact on the muscle system through relationship development between the maximum strength and the explosive strength for low parties. While the control sample made little progress that did not reach the level of statistical significance because the teacher was dependent on the skill side to a large extent at the expense of the physical aspect that plays an important role in achieving digital achievements in sports activities such as athletics competitions

Therefore, the researchers find that upgrading ability is essential and important to improve the digital achievement in the high jump. This coincides with (Essayed 2012) study which emphasizes on the application of physical exercises in adequate manner (redundancy, intensity and density). Malisoux (2006) that plyometric training contributes in the achievement improvement especially in the activities where muscle explosive contractions are used, and (Rahimi \& Behpur 2005) who mentioned that the plyometric training in short term has a great effect to power muscle and upgrading development.

Through Table 5 we see that there are significant differences between the post measurements for each of the experimental group and the control group on the level of muscular power and achievement high jump event pilot for the experimental sample, and this result indicates that plyometric exercise was more effective in improving performance in the applied in the high jump tests compared to the traditional method, which relies on memorization and performance of the model with the control sample, with the application of the jump group exercises in the preparatory part. This confirms that the use of plyometric exercise in line with the characteristics of the game is an important principle for effective educational situation a principle taking account the individual differences among students, and given an additional motivation for learning as a result of the use of devices and tools to assist in education and training, which led to attract the attention of the learner, to know the material process, and provide opportunities for creativity shown by the student during the course of the lesson. This is in line with the study of Wong et al. (2010), Damon et al. (2010), Charag et al. (2011), Suhail (2014), Essam (2014), Benzidane et al. (2015), Thakur et al. (2016) showing that: Plyometric exercises increase muscular power and are most effective when designed to complement the specific movements required of the athletic activity. Bal et al (2011) assured that the plyometric exercise is designed to improve strength of particular muscle. Therefore plyometric exercise needs to be integrated in other supporting exercise programmes so that it has exercise variation, the key of safe and effective plyometric program is based on the developing age and level of 
fitness

Finally Through the presentation of the previous results found that the program prepared according to scientific controls has resulted in the development of the muscular power of the muscles of the legs as the use of methods of training and different in a scientific as well as the use of different Intensity and rest periods sufficient to restore the healing and the number of its replication fits with the intensity of exercise as well as the use of body weight at elevations varying has led to the development of the explosive power of the muscles of the legs and this, which led to the development aspects of physical, and reflected this development on the technical performance and this was confirmed that the plyometric exercises are aimed at the physical qualities associated with the type of sports activity development.

\section{Conclusions}

- The plyometric exercises have a positive impact on the development muscular power (vertical jump) among students.

- The plyometric exercises have a positive impact on the development of digital achievement in highjump among students.

- The existence of statistically significant differences between the experimental and control groups in the post measurement in favor of the experimental group.

\section{Accordingly, we recommend the following:}

- Attention to the physical aspect of students.

- Improving students' strength and muscular capacity.

- The use of plyometric exercises within the educational and training programs among students.

- Improving the digital achievement in the jumping competition activities.

\section{Acknowledgements}

We appreciate all the people especially students who helped us to finalize this work.

\section{References}

1. ALPTEKIN KILIC, Ö. \& M. MAVIS, 2013. The effect of an 8-week plyometric training program on sprint and jumping performance. In: Serbian Journal of Sports Sciences. 7(2), pp.45-50.

2. BAL, B.S., P. J. Kaur \& D. Singh, 2011. Effects of a Short Term Plyometric Training Program of Agility in Young Basketball. In: Brazilian Journal of Biomotricity. 5(4), pp.271- 
278.

Retrieved from http://www.brjb.com.br/files/brjb 1635201112 id2.pdf.

3. BENSIKADDOUR, H., H. BENZIDANE, T. AHMED-BENKLAOUZ \& D. MOKRANI, 2015. The effect of using plyometric exercises to improve some physical abilities and performance I, the triple jump (Hop, Step, Jump).In: The Swedish Journal of Scientific Research. 2(11).

4. BENZIDANE, H., H. BENSIKADOUR, D. MOKRANI, 2015. Effect of plyometric training to improve a physical capacity and athletic performance to high school students (1718) Years Old. In: American Journal of Sports Science. 3(5), pp.98-102.

5. CHARAG, A., R. PAL \& S. YADAY, 2001. Effect of Plyometric Training on Muscular Power and Anaerobic Ability of the Noviced Sprinters. In: Asian Journal of Physical Education and Computer Science in Sports. 4(1), pp.77-81.

6. EDWARD, D., H. Jacqueline, T. O'Rourke \& S. Stolley, 1995. Track and Field Coaching Manuel. LA84 Foundation. All rights reserved. Printed in the USA.

7. ESSAM FATHY GHAREB, 2014. Effect of Plyometric Training with Different Intensities on Kinematics Variables in Fosbury-Flop High Jump. In: Ovidius University Annals, Series Physical Education and Sport Science, Movement and Health, Romania. 14(2), pp.251-256.

8. FAtOUROS, G., A.Z. JAMURTAS., D. LEONTSINI., K. TAXILDARIS., N. AGGELOUSIS \& P. BUCKENMEYER, 2000. Evaluation of Plyometric Exercise Training, Weight Training, and Their Combination on Vertical Jumping Performance and Leg Strength. In: Journal of Strength \& Conditioning Research. 14(4), pp.470-476.

9. GAMBETTA, G, 2007. Athletic development: The art \& science of functional sports conditioning. Champaign, Illinois: Human Kinetics.

10. HAMDI SOFIAN, 2001. Effect of two methods entrainment, plyometric and musculation, on Explosive by players of Soccer Canada. University of Québec à Montréal. pp. 02.

11. HENSON, P, 1994. Plyometric Training. Track and field. Quarterly Review of Jumps, pp.94-53.

12. HOLCOMP, W., J. Lander., R. Rutland \& G. Wilson, 1996. The effectiveness of a modified plyometric program on power and the vertical jump. In: Journal of Strength and Conditioning Research. 10,89-92.

13. THAKUR, J, S., MISHRA, K, M., RATHORE, V, S. (2016). Impact of plyometric training and weight training on vertical jumping ability. Turkish Journal of Sport and Exercise. 8(1), pp. 31-37

14. KOTZAMANIDIS, C, 2006. Effect of plyometric training on running performance and 
vertical jumping in prepubertal boys. In: $J$ Strength Cond Res. 20, pp. 441-445.

15. MAKARUK, H \& T. SACEWICZ, 2010. Effects of plyometric training on maximal power output and jumping ability. In: Human Movement. 11(1), pp. 17-22.

16. MALISOUX, L., M. FRANCAUX, H. Nielens \& D. Theisen, 2006. Stretch-shortening cycle exercises: An effective training paradigm to enhance power output of human single muscle fibers. In: J Appl Physiol. 100, pp.771- 779.

17. MOHAMED ABDELMAWGOUD ESSAYED, 2012. Effect of Plyometric Training on Specific Physical Abilities in Long Jump Athletes. IDOSI Publications .In: World Journal of Sport Sciences. 7 (2), pp.105-108.

18. MOKRANI, D., H. BENZIDANE, M.SEBBANE \& T. TAHAR, 2015. The reciprocal Relationship between training with weights and the plyometric training and their effect on the muscles capacities growth for basketball players. In: European journal of physical education and sport. 8(2), pp. 90-96.

19. MOORE, C.A., \& B.K. Schilling, 2005. Theory and Application of Augmented Eccentric Loading. In: National Strength and Conditioning Journal. 27(5), pp. 20- 27.

20. RAHIMI, R \& N. Behpur, 2005. The effect of plyometric, weight and plyometric- weight training on anaerobic power and muscular strength. In: Facta Univ Phys Educ Sport. 3(1), pp. 81-91.

21. RAMIREZ -CAMPILlO, R., C.Alvarez, C. HENRIQUEZ- OLGUIN, E.B. Baez, C. MARTINEZ, D.C. ANDRADE, 2014a. Effects of plyometric training on endurance and explosive strength performance in competitive middle- and long-distance runners. In: $J$. Strength Cond. Res. 28 , pp.97-104.

22. SOZBIR KERIM, 2016. Effects of 6-Week Plyometric Training on Vertical Jump Performance and Muscle Activation of Lower Extremity Muscles. In: U.S. Sports Academy, pp. 1-18. Retrieved from http://thesportjournal.org/article/effects-of-6-week-plyometrictraining-on-vertical-jump performance - and-muscle-activation-of-lower-extremity$\underline{\text { muscles/ }}$

23. STOJANOVIC, T \& R. Kostić, 2002. The effects of the plyometric sport training model on the development of the vertical jump of volleyball players. In: Facta Univ Phys Educ Sport. 1(9), pp.11-25.

24. THOMAS, K., D. French \& P.R. Hayes, 2009. The effect of plyometric training techniques on muscular power and agility in youth soccer players. In: J Strength Cond Res. 23, pp. 332 335.

25. WATHEN DAN, 1993. Literature Review: Explosive, Plyometric Exercises. In: National 
Strength and Conditioning Journal. 15(3),pp.17-19.

26. ZABCHI, N., D. MOKRANI, BENZIDANE, H \& M. SEBBANE, 2016. The Effect of the Contrastive Training Using Weights and Plyometric on the Development of the Vertical Jump Ability to Improve the Performance. In: European Journal of Physical Education and Sport. 11(1), pp.24-30. 